\title{
DIPHTHERITIC PARALYSIS AND ANTITOXINE.
}

\author{
By Dr. F. Ransom. \\ From Professor Behring's Laboratory, Mfarburg a/Lahn.
}

EVERY now and again one meets with the assertion that cases of postdiphtheritic paralysis are more frequent now than they were in the days before diphtheria antitoxine. The truth, or at least the probability of this statement might be readily conceded, for it has long been known that the severer forms of diphtheria are more liable than mild attacks to be followed by paralysis, so that it ought hardly to cause surprise if the life-saving action of the antitoxine, by raising the rate of recovery in severe cases and diminishing the death rate, should appear to increase the frequency of paralysis. It is, however, not unlikely that the idea of a more or less direct connection between the antitoxine treatment and the paralysis may have occurred to many. Under these circumstances it seemed to me worth while to undertake an examination into the conditions under which diphtheritic paralyses occur in animals, and to ascertain by means of experiments what effect, if any, the antitoxine has on this very disagreeable sequel to an attack of diphtheria.

It was evident that in order to carry out this task satisfactorily, it would be necessary to answer the following questions:-

1. In what numerical relation do the cases of paralysis stand to the number of intoxications?

2. What is the relation, if any, between the amount of toxine given and the severity or frequency of paralysis?

3. What are the results, so far as paralysis is concerned, when toxine and antitoxine are given mixed?

4. What are the results when antitoxine is given some hours after intoxication?

The series of investigations which I now report were designed to answer as clearly and concisely as possible the above questions, and so to put the matter on a firm basis of experimental facts.

I have selected guinea-pigs for the experiments, since, as is well known, they are liable to very characteristic post-diphtheritic paralysis. So far as the method of making the experiments is concerned, it is only necessary to note that the injections of toxine were always 
made under the left shoulder; the mixtures of toxine and antitoxine were injected in the same region, and, when antitoxine was given alone, the injection took place under the right shoulder.

In describing the paralyses, I have for the sake of clearness drawn a distinction between general and local symptoms. General paralysis is here to be understood as a weakness which manifests itself especially in the muscles of the neck, back, abdomen, and hind-legs. If the animal is laid on its back or side, it can only with difficulty resume its natural position; in severe cases it cannot turn itself over at all; when creeping, the jaw rests on the table, in consequence of the inability of the neck muscles to hold up the head; often the hind-legs are very limp, so that they lie slack behind the animal, which in severe cases can hardly drag itself about on the smooth surface of the laboratory table.

By local paralysis is meant a weakness or complete lameness of the left fore-leg, the limb in whose immediate neighbourhood the toxine was injected. When paralysis is complete, the leg is dragged about without itself taking any active part in the movement of the animal; it remains in any position in which it may be placed, e.g. stretched out to the right or drawn under the thorax to the left. In less pronounced cases the resistance to involuntary movement is weak and of short duration, and voluntary movements are only feebly carried out.

In order as far as possible to repeat the experiments under the conditions prevailing in the human being, when suffering from diphtheria, I have usually produced intoxication with the smallest certainly fatal dose, or with a fraction of this quantity.

The experiments were made in groups with varying numbers of animals, but each group was completed in one day. Two toxines were used, both of which were in the form of dry powder about 150 times the normal strength. ${ }^{1}$ That is to say, the smallest amount which would kill a guinea-pig with certainty between the third and fifth day was $\frac{\text { weight of animal }}{250 \times 100 \times 150}$ grms.

According to the regulation for workers in Professor Behring's laboratory, the expression " $1+\mathbf{M}$." indicates the smallest certainly lethal dose of a toxine for 1 grm. weight of guinea-pig; accordingly in the following tables " $1+M$. per 1 grm." means the smallest certainly fatal dose for the animal in question (the death must take place between the third and fifth day), and " $1 \frac{1}{2}+$ M. per 1 grm." shows that a dose half as large again as this lethal dose has been given.

In order to avoid as far as possible the difficulty in measuring the antitoxine dose caused by the so-called "D." value of Professor

${ }^{1} \Lambda$ normal diphtheria toxine has such a toxicity that 0.01 c.c. or grm. kills with certainty a guinea-pig of 250 grms. not before the third and not later than the fifth day. 
Ehrlich, I have employed with one exception a perfectly fresh toxine solution for each group. Reckoning, then, the toxine as 150 times, and the antitoxine as 250 times normal (i.e., 250 antitoxine units in 1 c.c.), I obtained a mixture, which, in the ordinary dose for the estimation of antitoxic value ( $1 \mathrm{~A}$. U. $+\frac{1}{\frac{1}{5}} 0 \mathrm{gr}$. toxine), produced no or very slight induration at the point of injection (Limes o). Accordingly, in the following tables, " $1-$ M. per 1 grm." (the minus sign toxine indicates antitoxine, just as the plus sign toxine) signifies weight of animal $\frac{250 \times 100 \times 250}{10 . c . ~ o f ~ s e r u m . ~}$

With the exception of one group, the toxine solutions were used within twenty-four hours after preparation. In order to control possible inequalities in the toxine solutions, each group contains one or more control animals treated with toxine alone. In calculating the doses of toxine and antitoxine, I have, as above indicated, started from the so-called normal guinea-pig of 250 grms. weight, and have made the dose smaller or larger, in proportion as the animal weighed more or less than 250 grms. I could not improvise any satisfactory method of allowing for the difference in susceptibility to toxine between younger and older animals, and so had to disregard this factor; most of the animals used were, however, of middle weight. It is to be especially observed that in the following tables the symptoms of local and general intoxication, as seen during the first few days after a dose of toxine, are entirely neglected, as also are limitations in the movements of the left fore-leg caused by swelling or necrosis. This report refers solely to the paralytic symptoms, which, when they occur at all, usually set in during the third or fourth week after intoxication.

After these introductory and explanatory remarks, I may proceed to the detailed examination of each group of experiments.

Group 1.-Diphtheria Toxine, No. 79a, in perfectly fresh Solution in Water.

TABLE I.

\begin{tabular}{|c|c|c|c|c|c|c|c|}
\hline \multirow{2}{*}{ Date. } & \multirow{2}{*}{$\begin{array}{l}\text { No. of } \\
\text { Animal. }\end{array}$} & \multirow{2}{*}{\multicolumn{2}{|c|}{ Weight. }} & \multirow{2}{*}{ Dose of Toxine. } & \multicolumn{2}{|c|}{ Paralysis. } & \multirow{2}{*}{ Result. } \\
\hline & & & & & General. & Local. & \\
\hline $\begin{array}{l}1899 . \\
\text { Mar. } 10\end{array}$ & 732 & 300 & grms. & $1+\mathbf{M}$. per 1 grm. & $\ldots$ & $\cdots$ & Died in $4 \frac{1}{2}$ \\
\hline " & 620 & 280 & , , & $\frac{1}{2}+\mathrm{M} . \quad$, & $\cdots$ & $\cdots$ & $\begin{array}{l}\text { Died in } 51 \\
\text { deys. }\end{array}$ \\
\hline$"$ & 621 & 310 & ", & $\$+\mathrm{MI} . \quad$, & $\begin{array}{l}\text { Moderate in } \\
4 \text { th week. }\end{array}$ & $\begin{array}{l}\text { Moderate in } \\
\text { 4th week. }\end{array}$ & $\begin{array}{l}\text { Recovered in } \\
\text { about } 6 \mathrm{wks}\end{array}$ \\
\hline$"$ & 751 & 280 & " & $\frac{1}{8}+\mathbf{M} . \quad$, & $\begin{array}{l}\text { Slight in } 4 \text { th } \\
\text { week. }\end{array}$ & 0 & $\begin{array}{l}\text { Recovered in } \\
\text { about } 6 \text { wks. }\end{array}$ \\
\hline$"$ & 760 & 210 & , & $\mathrm{T}^{1}=\mathrm{M}$ & $\ldots$ & 0 & $\cdots$ \\
\hline
\end{tabular}


The object of this series was to ascertain, in a preliminary experiment, whether the quantity of toxine given bears any relation to the occurrence or the severity of the paralysis. The table indicates that the severity of the paralysis is greater the larger the dose of toxine, and that at least $\frac{1}{12}$ of the minimal lethal dose may be given without paralysis ensuing.

Grovp 2.-Toxine and Antitoxine given apart. Toxine as in Group 1.

TABLE II.

\begin{tabular}{|c|c|c|c|c|c|c|c|c|c|}
\hline \multirow{2}{*}{ Date. } & \multirow{2}{*}{ 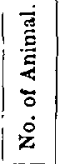 } & \multirow{2}{*}{\multicolumn{2}{|c|}{ Weight. }} & \multirow{2}{*}{ 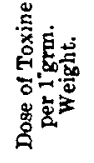 } & \multirow{2}{*}{ 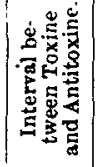 } & \multirow{2}{*}{ 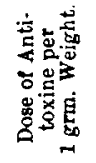 } & \multicolumn{2}{|c|}{ Paralysis. } & \multirow{2}{*}{ Result. } \\
\hline & & & & & & & General. & Local. & \\
\hline $\begin{array}{l}1899 . \\
\text { Mar. I5 }\end{array}$ & 21 & $250 \mathrm{~g}$ & rms. & $1+M$ & 22 hrs. & 0 & .. & $\cdots$ & $\begin{array}{l}\text { Died in } 2 \frac{1}{2} \\
\text { days. }\end{array}$ \\
\hline$"$ & 24 & 260 & $"$ & $\frac{1}{2}+\mathrm{M}$ & $"$ & $4-M$ & $\begin{array}{l}\text { Moderate in } \\
\text { 4th week. }\end{array}$ & $\begin{array}{l}\text { Moderate in } \\
\text { 4th week. }\end{array}$ & $\begin{array}{l}\text { Recovered in } \\
6 \text { weeks. }\end{array}$ \\
\hline " & 25 & 280 & " & $1+M$ & $"$ & $6-\mathrm{M}$ & $\cdots$ & $\cdots$ & $\begin{array}{l}\text { Died in } 2 \frac{1}{\text { days. }} \\
\text { day. }\end{array}$ \\
\hline " & 27 & 270 & ", & $1+M$ & $"$ & $8-\mathrm{M}$ & $\begin{array}{l}\text { Severe in } \\
\text { 3rd week. }\end{array}$ & $\cdots$ & $\begin{array}{l}\text { Died on the } \\
24 \text { th day. }\end{array}$ \\
\hline$"$ & 26 & 365 & $"$ & $I+M$. & $"$ & $12-M$ & $\cdots$ & $\cdots$ & $\begin{array}{l}\text { Died in } 2 \frac{1}{2} \\
\text { days. }\end{array}$ \\
\hline$"$ & 23 & 295 & $"$ & $1+\mathrm{M}$ & ", & $18-M$ & $\begin{array}{l}\text { Severe in } \\
\text { 4th week. }\end{array}$ & $\begin{array}{l}\text { Severe in } \\
\text { 4th week. }\end{array}$ & $\begin{array}{l}\text { Recovered in } \\
6 \text { weeks. }\end{array}$ \\
\hline
\end{tabular}

This group was arranged with the object of ascertaining whether and in what way the occurrence or the degree of paralysis could be affected by a small dose of antitoxine, given twenty-two hours after intoxication. The dose of antitoxine was purposely small, as the result shows, not even sufficient to save the lives of three of the four animals which received $1+\mathrm{M}$. per $1 \mathrm{grm}$. All the animals which survived the first three days suffered from paralysis. It may be taken for granted that Guinea-pig No. 27 would have shown local as well as general symptoms had it lived a few days longer. In this connection I may remark, that as a rule the general symptoms were first observed, and a few days later the local paralyses became evident; often the latter increased, whilst the former were improving. The usual date for the incidence of the general symptoms was about the twenty-first day, the local paralysis was usually first definitely diagnosed about the twenty-seventh or twenty-eighth day. We learn from this group that small doses of antitoxine given after intoxication with a half to one lethal dose do not prevent the occurrence of paralysis. 
Group 3.--Toxine and Antitoxine mixed before Injection. Toxine as in 1 and 2.

Table III.

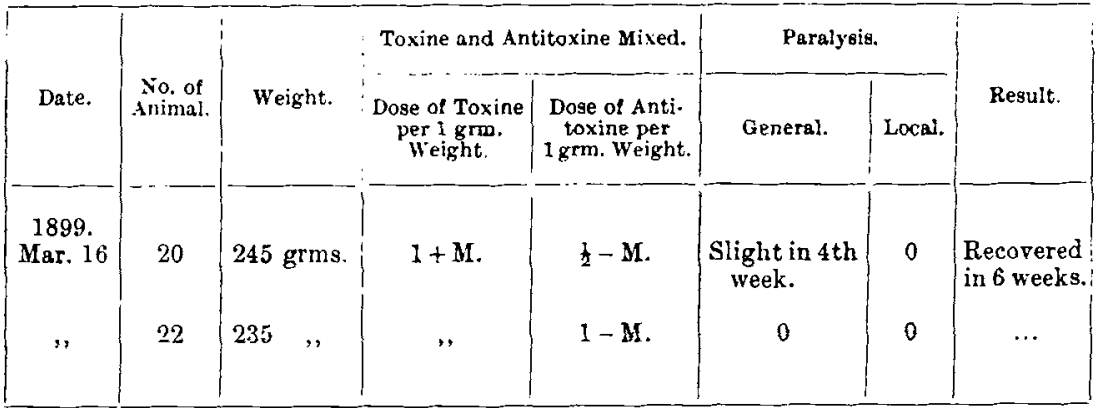

This small group teaches us that a mutually neutralised mixture of toxine and antitoxine need not produce paralysis, even when the dose of toxine is a lethal one. On the other hand, we see that a mixture, containing a less quantity of antitoxine than is necessary to neutralise the toxine present, was followed by distinct though slight paralysis. If Guinea-pig No. 20 be compared with No. 24 in Group 2 and with Nos. 31 and 32 in Group 4, it will be at once evident that in the cases of Nos. 20 and 32 the antitoxine has exercised a modifying effect on the paralysis.

GRoup 4.-Toxine as in 1, 2, and 3 .

TABLE IV.

\begin{tabular}{|c|c|c|c|c|c|c|c|}
\hline \multirow{2}{*}{ Date. } & \multirow{2}{*}{$\begin{array}{l}\text { No. of } \\
\text { Animal. }\end{array}$} & \multirow{2}{*}{ Weight. } & \multirow{2}{*}{$\begin{array}{l}\text { Dose of Toxine } \\
\text { per I grmi. } \\
\text { Weight. }\end{array}$} & \multicolumn{3}{|c|}{ Paralysis. } & \multirow{2}{*}{ Result. } \\
\hline & & & & General. & Local & & \\
\hline $\begin{array}{l}1899 . \\
\text { Mar. } 18\end{array}$ & 31 & 250 grms. & $\frac{1}{2}+M$ & $\begin{array}{l}\text { Severe in } 4 \text { th } \\
\text { week. }\end{array}$ & \multicolumn{2}{|c|}{$\begin{array}{l}\text { Moderate in } \\
4 \text { th week. }\end{array}$} & $\begin{array}{l}\text { Recovered in } \\
\text { about } 6 \text { weeks. }\end{array}$ \\
\hline \multirow[b]{2}{*}{ Date. } & \multirow[b]{2}{*}{$\begin{array}{c}\text { Fo. of } \\
\text { Aninal. }\end{array}$} & \multirow[b]{2}{*}{ Weight. } & \multicolumn{2}{|c|}{ Toxine and Antitoxine Mixed. } & \multicolumn{2}{|c|}{ Paralysis. } & \multirow[b]{2}{*}{ Result. } \\
\hline & & & $\begin{array}{l}\text { Dose of Toxine } \\
\text { per I grm. } \\
\text { Weight. }\end{array}$ & $\begin{array}{c}\text { Dose of Antí- } \\
\text { toxine per } \\
1 \text { grm. Weight. }\end{array}$ & General. & Local. & \\
\hline $\begin{array}{l}1899 . \\
\text { Mar. } 18\end{array}$ & 34 & 205 grms. & $1+\mathrm{M}$ & $\frac{1}{4}-\mathrm{M}$ & $\cdots$ & $\cdots$ & $\begin{array}{c}\text { Died in } 36 \\
\text { hours. }\end{array}$ \\
\hline$"$ & 32 & 225, & ", & $\frac{1}{2}-M$ & 0 & 0 & $\cdots$ \\
\hline
\end{tabular}


TABLE IV.-continued.

\begin{tabular}{|c|c|c|c|c|c|c|c|c|}
\hline \multirow[b]{2}{*}{ Date. } & \multirow{2}{*}{ 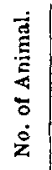 } & \multirow[b]{2}{*}{ Weight. } & \multirow{2}{*}{ 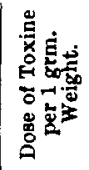 } & \multirow{2}{*}{ 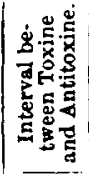 } & \multirow{2}{*}{ 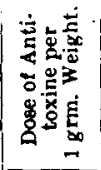 } & \multicolumn{2}{|c|}{ Paralysis. } & \multirow[b]{2}{*}{ Result. } \\
\hline & & & & & & General. & Local. & \\
\hline $\begin{array}{c}1899 . \\
\text { Mar. } 18\end{array}$ & 33 & $275 \mathrm{grms}$ & $1+M$ & $22 \mathrm{hrs}$ & B-M. & $\cdots$ & $\cdots$ & $\begin{array}{c}\text { Died in } 3 \frac{1}{2} \\
\text { days. }\end{array}$ \\
\hline$"$ & 30 & $235 \quad$ & " & ", & $12-\mathbf{M}$ & ... & $\ldots$ & $\begin{array}{l}\text { Died in } 2 \frac{1}{2} \\
\text { days. }\end{array}$ \\
\hline
\end{tabular}

Guinea-pig No. 31 supplies the vacancy in Group 1, caused by the early death of No. 620, and shows that $\frac{1}{2}+$ M. per 1 grm., that is the half of the minimal lethal dose, is sufficient to cause fairly severe paralysis. Guinea-pig No. 32 confirms the indication given by No. 20 in Group 3, that the admixture of antitoxine with the minimal lethal dose before injection has a favourable effect in reducing the chances of paralysis. Nevertheless, we see from No. 34 that the preponderance of toxine in the mixture must not be too great. Nos. 33 and 30 are useful as confirming the accuracy of the toxine dosage in the case of No. 31 .

Group 5.-Diphtheria Toxine No. 100 in perfectly fresh Solution in Water.

TABLE V.

\begin{tabular}{|c|c|c|c|c|c|c|c|}
\hline \multirow{2}{*}{ Date. } & \multirow{2}{*}{$\begin{array}{l}\text { No. of } \\
\text { Animal. }\end{array}$} & \multirow{2}{*}{\multicolumn{2}{|c|}{ Weight. }} & \multirow{2}{*}{$\begin{array}{l}\text { Dose of Toxine per } \\
1 \mathrm{grm} \text {. Weight. }\end{array}$} & \multicolumn{2}{|c|}{ Paralyais. } & \multirow{2}{*}{ Result. } \\
\hline & & & & & General. & Local. & \\
\hline $\begin{array}{l}1899 . \\
\text { Mar. } 21\end{array}$ & 38 & 250 & rms. & $1 \frac{1}{2}+\mathrm{M}$ & $\cdots$ & $\ldots$ & $\begin{array}{l}\text { Died in } 47 \\
\text { hours. }\end{array}$ \\
\hline$"$ & 37 & 250 & $"$ & $1+\mathbf{M}$ & $\cdots$ & $\cdots$ & $\begin{array}{l}\text { Died in } 3 \frac{1}{2} \\
\text { days. }\end{array}$ \\
\hline " & 40 & 230 & $"$ & $\mathbf{s}+\mathbf{M}$ & $\begin{array}{l}\text { Slight in 4th } \\
\text { week. }\end{array}$ & 0 & $\begin{array}{l}\text { Recovered in } \\
6 \text { weeks. }\end{array}$ \\
\hline " & 43 & 400 & ", & $\frac{1}{6}+M$ & 0 & 0 & $\cdots$ \\
\hline$"$ & 35 & 440 & ", & $+\mathrm{M}$. & $\begin{array}{l}\text { Slight in 4th } \\
\text { week. }\end{array}$ & 0 & $\begin{array}{l}\text { Recovered in } \\
5 \text { weeks. }\end{array}$ \\
\hline
\end{tabular}


TABLE V.—continued.

\begin{tabular}{|c|c|c|c|c|c|c|c|c|c|}
\hline \multirow[b]{2}{*}{ Date. } & \multirow[b]{2}{*}{$\begin{array}{l}\text { No. af } \\
\text { Animag }\end{array}$} & \multirow{2}{*}{\multicolumn{2}{|c|}{ Weight. }} & \multicolumn{3}{|c|}{ Toxine and Antitoxine Mixed. } & \multicolumn{2}{|c|}{ Paralysis. } & \multirow[b]{2}{*}{ Result. } \\
\hline & & & & $\begin{array}{l}\text { Dose of Toxine } \\
\text { per } 1 \text { grm. } \\
\text { Weight. }\end{array}$ & \multicolumn{2}{|c|}{$\begin{array}{l}\text { Dose of Anti. } \\
\text { toxine per } \\
1 \mathrm{grm} \text {. Weight. }\end{array}$} & General. & Local. & \\
\hline $\begin{array}{c}1899 . \\
\text { Mar.-21 }\end{array}$ & 45 & \multicolumn{2}{|c|}{505 grms. } & $1 \frac{1}{2}+M$ & \multicolumn{2}{|c|}{$2-\mathrm{M}$} & 0 & 0 & $\cdots$ \\
\hline , & 46 & \multicolumn{2}{|c|}{545,} & ", & \multicolumn{2}{|c|}{$1 \frac{1}{2}-\mathbf{M}$} & 0 & 0 & $\cdots$ \\
\hline , & 44 & \multicolumn{2}{|c|}{$460 \quad}$, & ", & \multicolumn{2}{|r|}{$1-\mathrm{M}$} & $\ldots$ & $\ldots$ & $\begin{array}{l}\text { Died in } 2 \frac{1}{2} \\
\text { days. }\end{array}$ \\
\hline " & 42 & \multicolumn{2}{|c|}{520,} & " & \multicolumn{2}{|r|}{$\frac{1}{2}-\mathrm{M}$} & $\ldots$ & ... & $\begin{array}{l}\text { Died in } 31 \\
\text { days. }\end{array}$ \\
\hline$"$ & 47 & 480 & $" s$ & $"$ & \multicolumn{2}{|c|}{$1-M}$. & $\cdots$ & $\cdots$ & $\begin{array}{l}\text { Died in } 2 \frac{1}{2} \\
\text { days. }\end{array}$ \\
\hline \multirow[b]{2}{*}{ Date. } & \multirow{2}{*}{ 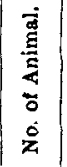 } & \multirow[b]{2}{*}{ Weight. } & \multirow{2}{*}{ 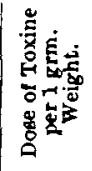 } & \multirow{2}{*}{ 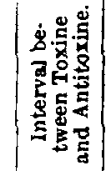 } & \multirow{2}{*}{ 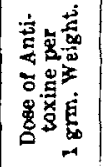 } & & Paralyeis. & & \\
\hline & & & & & & Genera & & Local. & Result. \\
\hline $\begin{array}{c}1899 . \\
\text { Mar. } 21\end{array}$ & 41 & $220 \mathrm{grms}$ & - $1 \frac{1}{2}+\mathrm{M}$ & 1. $16 \mathrm{hrs}$. & $6-M$. & ... & & $\cdots$ & $\begin{array}{c}\text { Died in } 43 \\
\text { hours. }\end{array}$ \\
\hline " & 39 & $210 \quad$, & 11 & " & $12-M$ & $\cdots$ & & $\cdots$ & $\begin{array}{l}\text { Died in } 50 \\
\text { hours. }\end{array}$ \\
\hline$"$ & 36 & $220 "$ & " & , & $18-M$ & $\ldots$ & & $\cdots$ & $\begin{array}{l}\text { Died in } 4 \hat{7} \\
\text { hours. }\end{array}$ \\
\hline
\end{tabular}

In the series of animals which received only toxine, we see that after one-third and one-eighth of the minimal fatal dose, slight paralysis occurred, whilst the animal which received one-fifth of the same dose escaped without any lumeness. We may take it, therefore, that a dose of toxine smaller than about one-fourth of the lethal dose does not with certainty cause paralysis. We see again, as in Group 3, that a mutually neutralised mixture of toxine and antitoxine, or a mixture in which antitoxine preponderates, is not followed by paralysis. By comparing Nos. 42, 44, and 47 with No. 38 , we obtain a confirmation of the accuracy of the toxine dosage, and the same may be said of the three last animals in the table. 
Group 6.-Toxine as in 5.

TABLE VI.

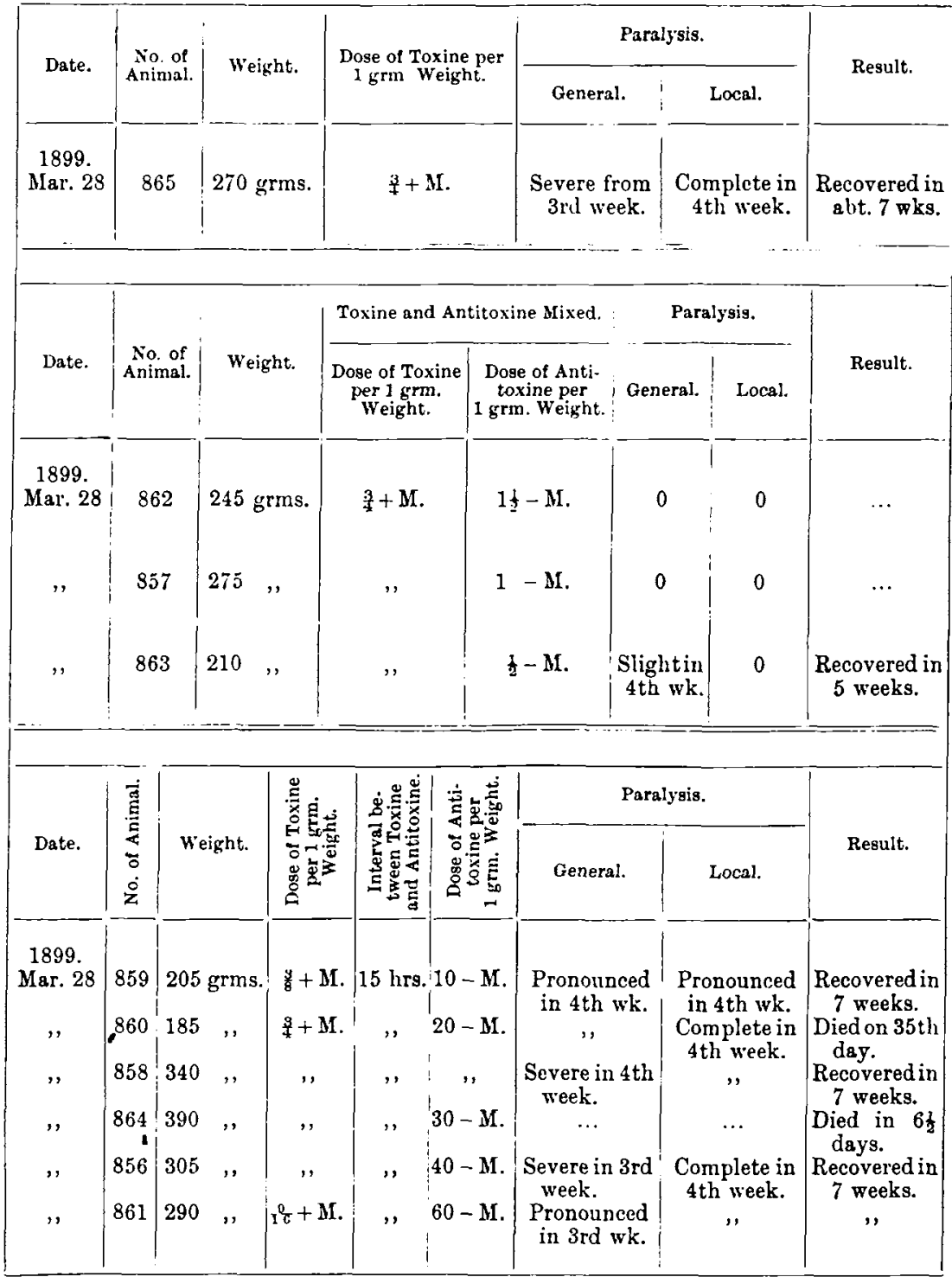

This group is especially instructive. We see, in the first place, that the control animal No. 865, which received three-fourths of the minimal lethal dose, developed severe paralysis, but eventually recovered. Of the whole group of ten animals, only two got through without paralysis, and they were just the two (Nos. 862 and 857) which had received a mixture of toxine and antitoxine with the latter in excess. In view of this fact, and bearing in mind the results 
obtained in the preceding groups, it is probably justifiable to conclude that no paralysis is to be feared after the injection of a mixture of toxine and antitoxine, in which the quantity of toxine does not much exceed the minimal lethal dose, whilst the antitoxine is in excess of the amount required for neutralisation. On the other hand, even a small preponderance of toxine in a mixture suffices to cause the development of paralysis (No. 863). Of the animals which received a dose of toxine first, and fifteen hours later a quantity of antitoxine, all who survived the first few days suffered from severe paralysis. This very noteworthy result makes it clear that antitoxine, given under the conditions and in the doses prevailing in this series, has no power to hinder the occurrence or alter the course of paralysis. Group 2 has taught us a similar lesson.

GROUP 7.

TABLE VII.

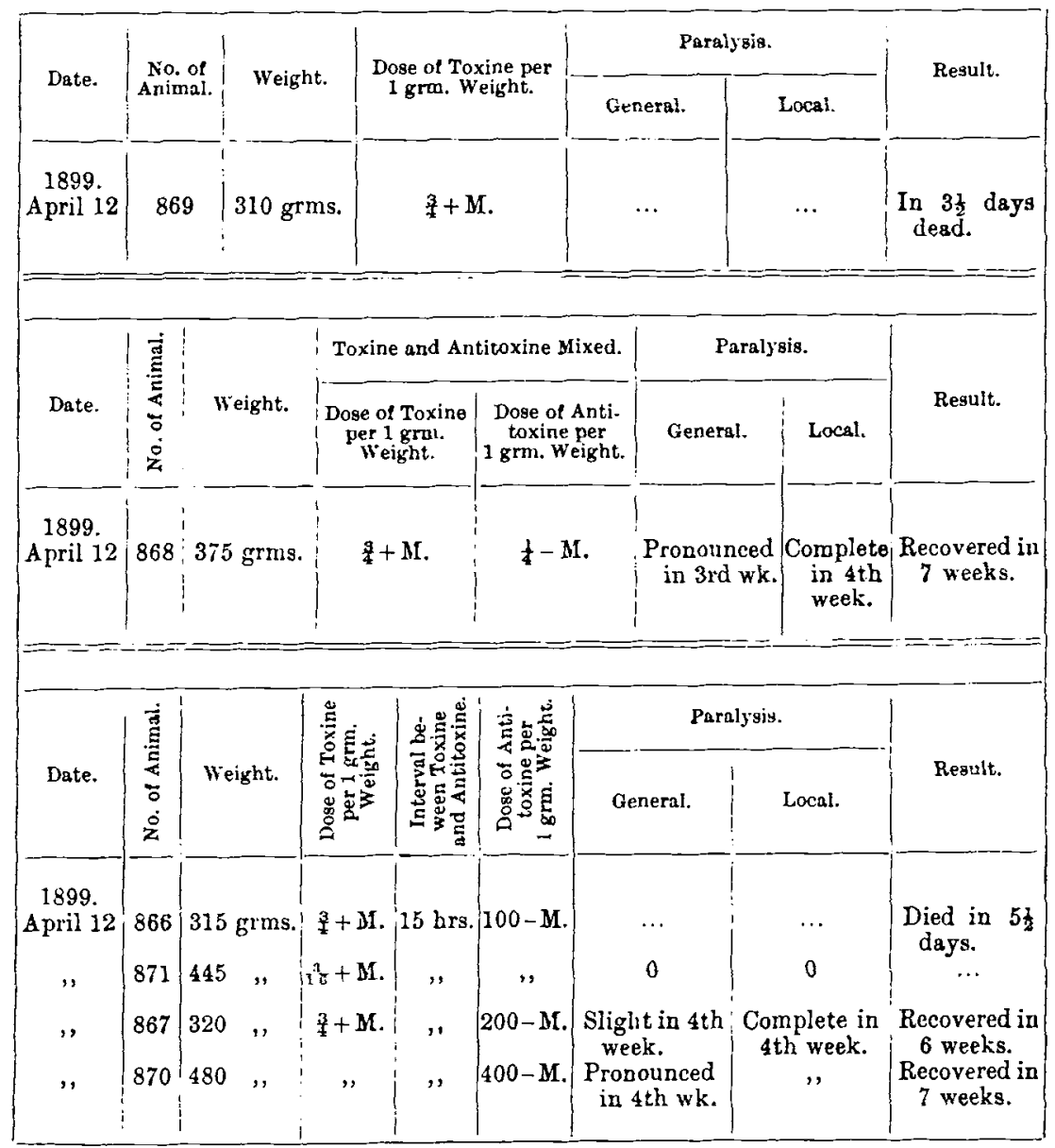


In the first place, it is interesting to compare Guinea-pig No. 868 with No. 863 in Group 6 . We see that a comparatively slight preponderance of toxine in mixture with antitoxine (No. 863) causes only slight paralysis, whereas, if the constitution of the mixture be altered to the disadvantage of the antitoxine (No. 868), a high degree of paralysis follows. In this group the doses of antitoxine given fifteen hours after intoxication were considerably larger than in the preceding group, nevertheless they did not suffice to prevent the occurrence of paralysis. In the case of Guinea-pig No. 871, the absence of paralysis cannot be attributed to the antitoxine, since it is not certain that $\frac{3}{16}$ of the minimum lethal dose would produce paralysis at all. On the other hand, the fact that in this case no paralysis occurred, allows the conclusion that the administration of antitoxine after intoxication does not increase the probability of paralysis.

\section{GROUP 8.}

TABLE VIII.

\begin{tabular}{|c|c|c|c|c|c|c|c|c|c|}
\hline \multirow{2}{*}{ Date. } & \multirow{2}{*}{\multicolumn{2}{|c|}{$\begin{array}{l}\text { No. of } \\
\text { Animal. }\end{array}$}} & \multirow{2}{*}{\multicolumn{2}{|c|}{ weight. }} & \multirow{2}{*}{\multicolumn{2}{|c|}{$\begin{array}{c}\text { Dose of Toxine per } \\
1 \text { grm. Weight. }\end{array}$}} & \multicolumn{2}{|c|}{ Paralysis. } & \multirow{2}{*}{ Result. } \\
\hline & & & & & & & teneral. & Local. & \\
\hline $\begin{array}{l}1899 . \\
\text { May } 4\end{array}$ & \multicolumn{2}{|c|}{56} & \multicolumn{2}{|c|}{$225 \mathrm{grms}$. } & \multicolumn{2}{|c|}{$\frac{z}{8}+\mathrm{M}$} & \multicolumn{2}{|l|}{$\cdots$} & $\begin{array}{l}\text { Died in } 50 \\
\text { hours. }\end{array}$ \\
\hline \multirow[b]{2}{*}{ Date. } & \multirow{2}{*}{$\left|\begin{array}{l}\dot{\Phi} \\
\stackrel{g}{E} \\
z \\
0 \\
0 \\
z\end{array}\right|$} & \multirow{2}{*}{\multicolumn{2}{|c|}{ Weight. }} & $\stackrel{\mathscr{E}}{\underline{\Sigma}}$ & \multirow{2}{*}{ 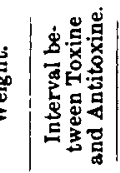 } & \multirow{2}{*}{ 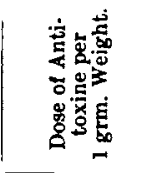 } & \multicolumn{2}{|c|}{ Paralygie. } & \multirow[b]{2}{*}{ Result. } \\
\hline & & & & 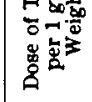 & & & General. & Local. & \\
\hline $\begin{array}{l}1899 . \\
\text { May } 4\end{array}$ & 34 & 265 & grms. & $\frac{7}{10}+M$. & [. $15 \mathrm{hrs}$. & $1,000-\mathrm{M}$ & 0 & $\begin{array}{l}\text { Slight in 4th } \\
\text { week. }\end{array}$ & $\begin{array}{l}\text { Recovered in } \\
5 \text { weeks. }\end{array}$ \\
\hline " & 57 & 225 & $"$ & $f+\mathrm{M}$ & " & $2,000-\mathrm{M}$ & 0 & , & ", \\
\hline$"$ & 40 & 225 & , & $\frac{5}{8}+\mathrm{M}$ & c. & $4,000-M$ & 0 & " & " \\
\hline " & 58 & 225 & ", & $f+\mathbf{M}$ & 6. & $10,000-\mathbf{M}$ & $\cdots$ & $\cdots$ & $\begin{array}{l}\text { Died in } 2 \frac{1}{2} \\
\text { dsys. }\end{array}$ \\
\hline
\end{tabular}

Unfortunately the control of Guinea-pig No. 56 died prematurely, so that we are deprived of a direct measure of the paralysis; but Nos. 34, 57, and 40 got off comparatively easily, a result which must probably be ascribed to the large doses of antitoxine. It is interest- 
ing to notice that in these cases the influence of the antitoxine made itself chiefly felt on the general symptoms.

\section{Group 9.-Toxine, the five-days old solution from Group 8, reckoned as 100 times normal.}

TABLE IX.

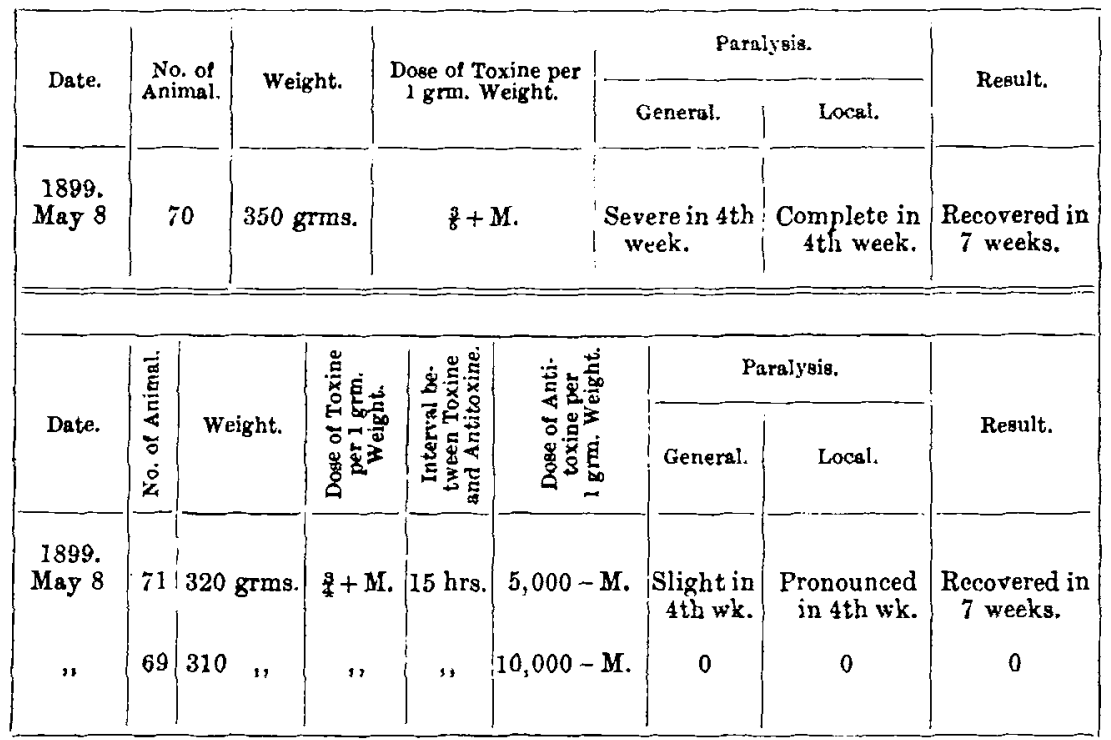

Although the control guinea-pig (No. 70) was severely paralysed, yet of the other two animals, both of which received rather larger doses of toxine, the one (No. 71) got off better than the control, and the other (No. 69) had no paralysis at all. This result can hardly be attributed to anything but the large doses of antitoxine, and this opinion is confirmed by a comparison with preceding groups, especially No. 6 . I call especial attention to the two control animals, No. 865 in Group 6, and No. 70 in Group 9.

Group 10.-Toxine as for 5, 6, 7, and 8 .

TABLE X.

\begin{tabular}{|c|c|c|c|c|c|c|}
\hline \multirow{2}{*}{ Date. } & \multirow{2}{*}{$\begin{array}{l}\text { No. of } \\
\text { Animal }\end{array}$} & \multirow{2}{*}{ Weight. } & \multirow{2}{*}{$\begin{array}{l}\text { Dose of Toxine per } \\
1 \mathrm{grm} \text {. Weight. }\end{array}$} & \multicolumn{2}{|c|}{ Paralygis. } & \multirow{2}{*}{ Result } \\
\hline & & & & Genera!. & Local. & \\
\hline $\begin{array}{r}1899 \\
\text { June } 14\end{array}$ & $71 \mathrm{~A}$ & 445 grms. & $\frac{5}{6}+\mathrm{M}$ & $\begin{array}{l}\text { Severe in } 4 \text { th } \\
\text { week. }\end{array}$ & $\begin{array}{l}\text { Moderate in } \\
\text { 4th week. }\end{array}$ & $\begin{array}{l}\text { Recovered in } \\
6 \text { weeks. }\end{array}$ \\
\hline ", & 67 & 380 & $f+M$ & ", & $\begin{array}{l}\text { Pronounced } \\
\text { in } 4 \text { th wk. }\end{array}$ & $\begin{array}{l}\text { Died on 28th } \\
\text { day. }\end{array}$ \\
\hline
\end{tabular}


TABLE X.-continued.

\begin{tabular}{|c|c|c|c|c|c|c|c|c|c|}
\hline \multirow{2}{*}{ Date. } & \multirow{2}{*}{ 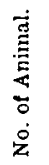 } & \multirow{2}{*}{\multicolumn{2}{|c|}{ Weight. }} & \multirow{2}{*}{ 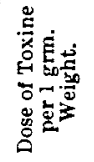 } & \multirow{2}{*}{ 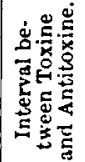 } & \multirow{2}{*}{ 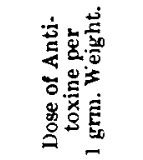 } & \multicolumn{2}{|c|}{ Paralysis. } & \multirow{2}{*}{ Result. } \\
\hline & & & & & & & General. & Local. & \\
\hline $\begin{array}{l}1899 . \\
\text { June } 14\end{array}$ & 12 & $290 \mathrm{~g}$ & $\mathrm{rms}$. & $8+\mathrm{MI}$ & 15 lirs. & $5,000-\mathbf{M}$ & $\begin{array}{l}\text { Slight and } \\
\text { brief in } 3 r d \\
\text { week. }\end{array}$ & $\begin{array}{l}\text { Slight in } \\
\text { 3rd wk. }\end{array}$ & $\begin{array}{l}\text { Recovered in } \\
4 \text { weeks. }\end{array}$ \\
\hline ", & 16 & 310 & " & ," & $"$ & $10,000-\mathrm{M}$ & $\begin{array}{c}0 \\
\text { or trace. }\end{array}$ & 0 & $\cdots$ \\
\hline$"$ & 13 & 300 & ", & ," & "' & $20,000-\mathrm{M}$ & 0 & $\begin{array}{c}0 \\
\text { or trace. }\end{array}$ & $\cdots$ \\
\hline ", & 15 & 290 & " & " & "י & ', & $\begin{array}{l}\text { Quite slight } \\
\text { in 3rd wk. }\end{array}$ & $\begin{array}{l}\text { Slight in } \\
\text { 3rd wk. }\end{array}$ & $\cdots$ \\
\hline " & 153 & 420 & ", & $\frac{5}{3}+M$ & ," & $30,000-\mathbf{M}$ & 0 & 0 & $\ldots$ \\
\hline " & 14 & 270 & ", & $\frac{1}{1} \mathrm{f}+\mathrm{M}$ & ", & $40,000-\mathrm{M}$ & $\begin{array}{l}\text { Slight and } \\
\text { brief in } 3 \mathrm{r} d \\
\text { week. }\end{array}$ & $\begin{array}{r}\text { Slight in } \\
\text { 3rd wk. }\end{array}$ & $\cdots$ \\
\hline
\end{tabular}

The two control animals, Nos. $71 \mathrm{~A}$ and 67 , were characteristic examples of diphtheritic paralysis, whereas the other guinea-pigs of the series, which received large doses of antitoxine, either got off without any paralysis or were comparatively slightly affected. Nevertheless, it is of great importance to note that the antitoxine, in spite of the very large doses in which it was given, did not, with the exception of one case, entirely prevent the occurrence of paralysis, and the exception was just the animal which had received the smallest dose of toxine (No. 153). The contents of this table are of great importance in relation to the conclusions which can be drawn from the whole series of experiments, because they indicate very clearly that the antitoxine treatment of diphtheria cannot be expected to prevent the occurrence of paralysis.

With the object of answering the questions placed in the beginning of this paper, I now proceed to the consideration of the series of ten groups as a whole.

In the first place, and referring only to simple intoxication, without the administration of antitoxine. We desire to learn in what relation the occurrence and the severity of paralysis stands to the quantity of toxine given; and, secondly, with what constancy paralysis occurs in those animals which have received a sufficient dose of toxine. Table XI. serves to enlighten us on these points. It contains all the animals out of the ten groups which were 
treated with toxine alone and did not die within the first four days after intoxication.

TABLE XI.

\begin{tabular}{|c|c|c|c|c|c|c|c|}
\hline \multirow{2}{*}{ Table. } & \multirow{2}{*}{$\begin{array}{c}\text { No, of } \\
\text { Animal. }\end{array}$} & \multirow{2}{*}{\multicolumn{2}{|c|}{ Weight. }} & \multirow{2}{*}{$\begin{array}{l}\text { Doge of Toxine per } \\
\text { ' grm. Weight. }\end{array}$} & \multicolumn{2}{|c|}{ Paralysis. } & \multirow{2}{*}{ Result. } \\
\hline & & & & & General. & Local. & \\
\hline I. & 760 & 210 & srmis. & $x^{2} \frac{1}{2}+31$. & 0 & 0 & $\ldots$ \\
\hline I. & 751 & 280 & , & $\frac{1}{8}+\mathrm{M}$. & Slight. & 0 & Recovered. \\
\hline v. & 35 & 440 & , & ", & ", & 0 & $"$ \\
\hline v. & 43 & 400 & $"$ & $t+M$ & 0 & 0 & $\ldots$ \\
\hline 1. & 621 & 310 & ," & $1+\mathbf{H}$ & Moderate. & Moderate. & Recovered. \\
\hline v. & 40 & 230 & ", & $b+M$ & Slight. & 0 & " \\
\hline IV. & 31 & 250 & ", & $\frac{1}{2}+\mathrm{M}$. & Severe. & Noderate. & " \\
\hline $\mathrm{x}$. & $71 \mathrm{~A}$ & 445 & $"$ & $\frac{8}{8}+M$. & " & " & " \\
\hline IX. & 70 & 350 & , & $z+M$ & ", & Complete. & ," \\
\hline $\mathrm{x}$. & 67 & 380 & . & $F+M$ & " & Pronounced. & $\begin{array}{l}\text { Died on } 28 \text { th } \\
\text { day. }\end{array}$ \\
\hline VI. & 865 & 240 & , & $+\mathbf{M}$. & " & Complete. & Recovered. \\
\hline
\end{tabular}

The indications are quite unmistakable: after quantities of toxine up to about one-fifth of the minimal lethal dose paralyses either do not occur at all or are very slight; after about one-fourth to onethird of the minimal lethal dose we see slight or moderate paralysis, and after a half or more of the minimal lethal dose pronounced paralysis occurred in every case. In short, after about one-fourth of the minimal lethal dose paralysis may uswally be expected, after one-half or more it always occurs. This table further teaches us that the larger the dose of toxine the more severe will be the paralysis. Of course, these conclusions refer, strictly speaking, only to the two toxines used in these experiments. Nevertheless, remembering universal clinical experience, we may probably accept them as generally applicable, even if, as is not unlikely, toxines of different origins should differ slightly in paralytic activity.

We can now turn our attention to the animals which were injected with a mixture of toxine and antitoxine. Table XII. contains all the guinea-pigs treated in this way. 
TABLE XII.

\begin{tabular}{|c|c|c|c|c|c|c|c|c|}
\hline \multirow[b]{2}{*}{ Table. } & \multirow{2}{*}{ 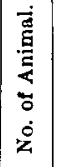 } & \multirow{2}{*}{\multicolumn{2}{|c|}{ Weight. }} & \multicolumn{2}{|c|}{ Toxine and Antitoxine Mixed. } & \multicolumn{2}{|c|}{ Paralysis. } & \multirow[b]{2}{*}{ Result. } \\
\hline & & & & $\begin{array}{c}\text { Dose of Toxine } \\
\text { per } 1 \text { grm. } \\
\text { Weight. }\end{array}$ & $\begin{array}{l}\text { Dose of Anti. } \\
\text { toxine per } \\
\text { grm. Weight. }\end{array}$ & Generai. & Local. & \\
\hline $\mathrm{v}$. & 45 & $505 \mathrm{~g}$ & grns. & $1 \frac{1}{2}+M$ & $2+M$ & 0 & 0 & $\ldots$ \\
\hline V. & 46 & 545 & , & ", & $1 t-\mathrm{MI}$ & 0 & 0 & $\ldots$ \\
\hline v. & 47 & 480 & , & ," & $1-\mathrm{MI}$ & $\ldots$ & $\ldots$ & $\begin{array}{l}\text { Died in } 2 t \\
\text { days. }\end{array}$ \\
\hline V. & 42 & 520 & , & , & $\frac{1}{2}-\mathrm{MI}$ & $\ldots$ & $\ldots$ & $\begin{array}{c}\text { Died in } 3 \frac{1}{2} \\
\text { days. }\end{array}$ \\
\hline$v$. & 44 & 460 & , & , & $\frac{1}{4}-M$ & ... & $\ldots$ & $\begin{array}{c}\text { Died in } 2 \\
\text { days. }\end{array}$ \\
\hline III. & 22 & 235 & , & $1+M$ & $1-\mathrm{MI}$ & 0 & 0 & $\cdots$ \\
\hline III. & 20 & 245 & $"$ & , & $\frac{1}{2}-M$ & $\begin{array}{l}\text { Slight in } 4 \text { th } \\
\text { week. }\end{array}$ & 0 & $\begin{array}{l}\text { Recovered in } \\
6 \text { weeks. }\end{array}$ \\
\hline IV. & 32 & 225 & $"$ & , & , & 0 & 0 & $\cdots$ \\
\hline IV. & 34 & 205 & , & , & $\frac{1}{4}-M$ & $\ldots$ & $\ldots$ & $\begin{array}{c}\text { Died in } 36 \\
\text { hours. }\end{array}$ \\
\hline VI. & 862 & 245 & , & $+\mathrm{M}$ & $1 \frac{1}{2}-\mathrm{M}$. & 0 & 0 & $\ldots$ \\
\hline VI. & 8.57 & 275 & ", & ," & $1-\mathrm{M}$ & 0 & 0 & $\ldots$ \\
\hline VI. & 863 & 210 & , & ," & $\frac{1}{2}-\mathrm{M}$ & Slight. & 0 & $\begin{array}{l}\text { Recovered in } \\
5 \text { weeks. }\end{array}$ \\
\hline VII. & 868 & 375 & , & " & 1-M. & $\begin{array}{r}\text { Pronounced } \\
\text { in 3rd wk. }\end{array}$ & $\begin{array}{c}\text { Complete in } \\
4 \text { th week. }\end{array}$ & $\begin{array}{l}\text { Recovered in } \\
7 \text { weeks. }\end{array}$ \\
\hline
\end{tabular}

It is at once evident that the table contains very few cases of paralysis, and a closer examination shows that they are confined to the animals which had received mixtures with toxine in excess. The conclusion appears perfectly justified, that neutralised mixtures of small doses of toxine and antitoxine do not cause paralysis. The like appears from the reports of Madsen, Woodhead, and others, to hold generally for neutralised mixtures with large multiples of the lethal dose. On the other hand, when the mixture contains a deficiency of antitoxine we have paralysis, and the greater the discrepancy is between toxine and antitoxine the severer is the paralysis.

Finally, we have to analyse the list of the animals which were treated with antitoxine after having previously received a dose of 
toxine. Table XIII. contains all these animals with the exception of such as died within four to five days.

TABLE XIII.

\begin{tabular}{|c|c|c|c|c|c|c|c|c|c|}
\hline \multirow{2}{*}{ Table. } & \multirow{2}{*}{ 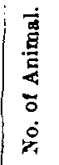 } & & \multirow{2}{*}{ eight. } & \multirow{2}{*}{ 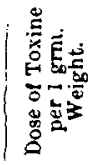 } & \multirow{2}{*}{ 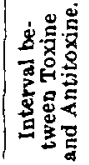 } & \multirow{2}{*}{ 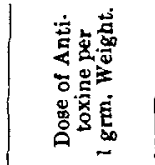 } & \multicolumn{2}{|c|}{ Paralysis. } & \multirow{2}{*}{ Result. } \\
\hline & & & & & & & General. & Local. & \\
\hline VII. & 871 & 445 & rrms & $\frac{3}{10}+M$ & $25 \mathrm{hrs}$. & $100-M I$ & 0 & 0 & $\ldots$ \\
\hline VI. & 859 & 205 & " & $\frac{3}{8}+M$. & $"$ & $10-M$ & Pronounced. & Pronounced. & Recovered in \\
\hline II. & 24 & 260 & , & $\frac{1}{2}+M$. & 22 hrs. & $4-M I$ & Moderate. & Moderate. & Recovered in \\
\hline VIII. & 40 & 225 &, & $s+M$. & $15 \mathrm{hrs}$ & $4,000-M$ & 0 & Slight. & Recovered in \\
\hline VI. & 861 & 290 & $"$ & $\frac{0}{10}+M$ & , & $60-M$ & Pronounced. & Complete. & Recovered in \\
\hline VIII. & 34 & 265 & $"$ & $t^{7} \sigma+M$. & ", & $1,000-\mathrm{M}$. & 0 & Slight. & $\begin{array}{l}\text { Recovered in } \\
5 \text { weeks. }\end{array}$ \\
\hline $\mathrm{X}$. & 153 & 420 & " & $\frac{5}{8}+\mathbf{M}$ & $s t$ & $30,000-\mathrm{M}$ & 0 & 0 & $\ldots$ \\
\hline VI. & 860 & 185 & , & $\frac{3}{5}+\mathrm{M}$ & s & $20-\mathrm{M}$ & Pronounced. & Complete. & Died on 35 th \\
\hline VI. & 858 & 340 & $"$ & $"$ & ," & ", & Severe. & " & $\begin{array}{c}\text { Recovered in } \\
7 \text { weeks. }\end{array}$ \\
\hline VI. & 856 & 305 & , & ", & ", & $40-\mathrm{MI}$. & ," & ," & , \\
\hline VII. & 867 & 320 & , , & , & ," & $200-\mathrm{M}$ & Slight. & ", & $\begin{array}{l}\text { Recovered in } \\
6 \text { weeks. }\end{array}$ \\
\hline VII. & 870 & 480 & ", & ", & ", & $400-\mathrm{M}$ & Pronounced. & $"$ & $\begin{array}{l}\text { Recovered in } \\
7 \text { weeks. }\end{array}$ \\
\hline IX. & 71 & 320 & , & " & $"$ & $5,000-\mathrm{M}$ & Slight. & Pronounced. & , \\
\hline IX. & 69 & 310 & " & " & ", & $10,000-\mathrm{M}$ & 0 & 0 & $\cdots$ \\
\hline VIII. & 57 & 225 & , & $\frac{4}{5}+\mathrm{M}$. & ", & $2,000-M$ & 0 & Slight. & $\begin{array}{c}\text { Recovered in } \\
7 \text { weeks. }\end{array}$ \\
\hline $\mathrm{x}$. & 12 & 290 & $"$ & $5 \mathrm{M}$. & ", & $5,000-\mathbf{M}$ & Slight. & ," & $\begin{array}{l}\text { Recovered in } \\
4 \text { weeks. }\end{array}$ \\
\hline X. & 16 & 310 & $"$ & " & " & $10,000-\mathbf{B}$ & $\begin{array}{c}0 \\
\text { or tuace. }\end{array}$ & 0 & $\ldots$ \\
\hline $\mathrm{x}$. & 13 & 300 & , & ," & $"$ & $20,000-M$ & 0 & $\begin{array}{c}0 \\
\text { or trace. }\end{array}$ & $\cdots$ \\
\hline $\mathrm{X}$. & 15 & 290 & , & ", & ", & $20,000-\mathbf{M}$ & Slight. & Slight. & $\begin{array}{c}\text { Recovered in } \\
4 \text { weeks. }\end{array}$ \\
\hline $\mathrm{X}$. & 14 & 270 & , & $\frac{1}{t}+\mathrm{MI}$. & ", & $40,000-\mathrm{M}$ & Slight. & Slight. & $\begin{array}{l}\text { Recovered in } \\
4 \text { weeks. }\end{array}$ \\
\hline II. & 27 & 270 & , , & $1+M$ & $22 \mathrm{hrs}$. & $8-M$ & Severe. & $\ldots$ & $\begin{array}{l}\text { Died on } 24 t h \\
\text { doy. }\end{array}$ \\
\hline II. & 23 & 295 & ", & ", & " & $18-\mathrm{M}$ & , & Severe. & $\begin{array}{l}\text { Recovered in } \\
6 \text { weeks. }\end{array}$ \\
\hline
\end{tabular}

The table is arranged according to the dose of toxine, the smallest being at the top. A glance shows that the quantity of toxine, though not without influence, is indecisive for the degree of paralysis. Up to a certain point the paralyses increase in severity with increasing doses of toxine: this point is reached when the doses of antitoxine were made large, from this point onward the paralysis was on the whole mild in spite of larger doses of toxine. 
In order to make the conditions somewhat clearer, I have in Table XIV. rearranged the same animals according to the doses of antitoxine.

\section{TABLE XIV.}

\begin{tabular}{|c|c|c|c|c|c|c|c|c|c|}
\hline \multirow{2}{*}{ Table. } & \multirow{2}{*}{ 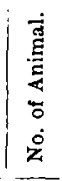 } & \multirow{2}{*}{\multicolumn{2}{|c|}{ Weight. }} & \multirow{2}{*}{ 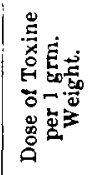 } & \multirow{2}{*}{ 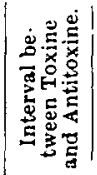 } & \multirow{2}{*}{ 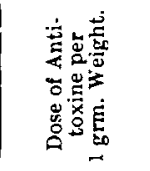 } & \multicolumn{2}{|c|}{ Paralysis. } & \multirow{2}{*}{ Result. } \\
\hline & & & & & & & General. & Local. & \\
\hline II. & 24 & 260 & grms. & $\frac{1}{2}+M$ & $22 \mathrm{hrs}$. & $4-\mathrm{M}$ & Moderate. & Moderate. & Recovered in \\
\hline II. & 27 & 270 & $"$ & $1+M$ & , & $8-\mathrm{M}$ & Severe. & $\ldots$ & $\begin{array}{l}\text { Died on } 24 \text { th } \\
\text { day. }\end{array}$ \\
\hline VI. & 859 & 205 & " & $\frac{Y}{8}+\mathrm{M}$ & $15 \mathrm{hrs}$. & $10-\mathbf{M}$ & Pronounced. & Pronounced. & Recovered in \\
\hline II. & 23 & 295 & " & $1+M$ & $22 \mathrm{hrs}$ & $18-\Lambda I$. & Severe. & Severe. & $\begin{array}{l}\text { Recovered in } \\
6 \text { weeks. }\end{array}$ \\
\hline VI. & 860 & $18 j$ & , & $\frac{3}{4}+\mathbf{M}$ & $15 \mathrm{hrs}$. & $20-\mathrm{M}$ & Pronounced. & Complete. & $\begin{array}{l}\text { Died on } 35 \text { th } \\
\text { day. }\end{array}$ \\
\hline VI. & 858 & 340 & , & " & ", & $20-\mathrm{MI}$ & Severe. & ", & $\begin{array}{l}\text { Recovered in } \\
7 \text { weeks. }\end{array}$ \\
\hline VI. & 856 & 305 & , & " & ", & $40-M$ & $"$ & , & , \\
\hline VI. & 861 & 290 & , & $\mathrm{I}^{9} \mathrm{X}+\mathrm{IL}$ & , & $60-M$ & Pronounced. & , & $"$ \\
\hline VII. & 871 & 445 & $"$ & $\frac{3}{10}+M$. & ", & $100-\mathbf{M}$ & 0 & 0 & $\cdots$ \\
\hline VII. & 867 & 320 & " & $3+\mathrm{M}$ & , & $200-\mathrm{M}$ & Slight. & Complete. & $\begin{array}{c}\text { Recovered in } \\
6 \text { weeks. }\end{array}$ \\
\hline VII. & 870 & 480 & , & $"$ & " & $400-\mathrm{M}$ & Pronounced. & ," & $\begin{array}{c}\text { Recovered in } \\
7 \text { weeks. }\end{array}$ \\
\hline VIII. & 34 & 265 & ", & $\frac{7}{10}+\mathrm{M}$ & , & $1,000-\mathrm{M}$ & 0 & Slight. & $\begin{array}{l}\text { Recovered in } \\
5 \text { weeks. }\end{array}$ \\
\hline VIII. & 57 & 225 & ", & $z+\mathbf{M}$ & $"$ & $2,000-\mathbf{M}$ & 0 & , & $"$ \\
\hline VIII. & 40 & 225 & $" \prime$ & $\frac{6}{0}+\mathrm{M}$ & , & $4,000-\mathrm{M}$ & 0 & $"$ & ," \\
\hline IX. & 71 & 320 & $"$, & $3+\mathrm{M}$ & ", & 5,000-M. & Slight. & Pronounced. & $\begin{array}{c}\text { Recovered in } \\
7 \text { weeks. }\end{array}$ \\
\hline$X$. & 12 & 290 & , & $\frac{5}{8}+1 \mathrm{II}$ & ," & $5,000-\mathrm{M}$ & ", & Slight. & $\begin{array}{c}\text { Recovered in } \\
4 \text { weeks. }\end{array}$ \\
\hline $\mathrm{X}$. & 16 & 310 & $"$ & $"$, & ," & $10,000-M$ & 0 & 0 & $\cdots$ \\
\hline IX. & 69 & 310 & $"$ & $\mathbf{3}+\mathbf{M}$ & , & $10,000-\mathrm{M}$ & 0 & 0 & $\cdots$ \\
\hline $\mathrm{X}$. & 13 & 300 & , & $5+\mathrm{M}$ & , & $20,000-\mathrm{M}$ & 0 & 0 & $\cdots$ \\
\hline $\mathrm{x}$. & 15 & 290 & ", & 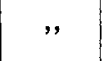 & ", & $20,000-\mathrm{M}$ & Slight. & Slight. & $\begin{array}{c}\text { Recovered in } \\
4 \text { weeks. }\end{array}$ \\
\hline $\mathrm{x}$. & 153 & 420 & , & $\frac{5}{8}+M$ & $"$ & $30,000-\mathbf{M}$ & 0 & 0 & .. \\
\hline $\mathrm{X}$. & 14 & 270 & ", & $\frac{1}{1} \mathrm{f}+\mathrm{M}$. & ", & $40,000-\mathrm{MI}$ & Slight. & Slight. & $\ldots$ \\
\hline
\end{tabular}

It is now evident that with increased antitoxine doses the paralyses decrease in severity, and even now and then do not appear at all. But-and this is a point of the greatest importance-not even the largest doses of antitoxine suppressed the paralysis with certainty. 
TABLE XV.

(a) Toxine $79 \mathrm{~A}$.

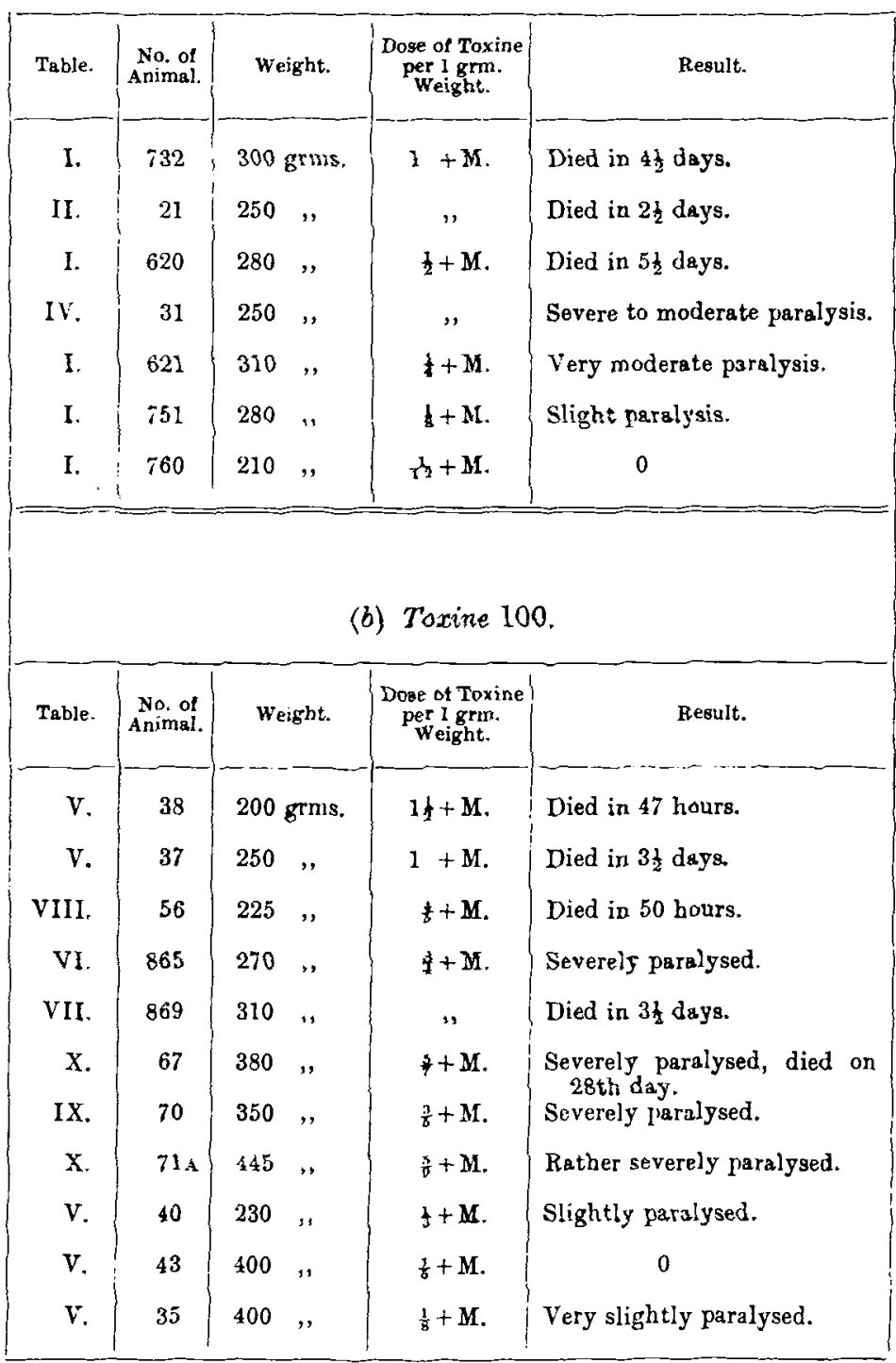

I have here brought together all the animals to which toxine alone was given. The table shows what may be called the paralytic latitude of the two toxines, that is, the difference between the smallest and largest dose which produces paralysis. The latter is of course a little less than the minimal fatal dose. The number of animals is too small to give great accuracy, and, of course, the conclusions drawn refer in the first place only to the two toxines used; nevertheless, the two series may be worthy of somewhat closer consideration. In the 
first place, it appears that, with one exception, all the animals which received one-eighth or more of the minimal lethal dose were later on more or less paralysed. This means that the paralytic latitude takes up seven-eighths, or 87 per cent. of the distance from 0 to a little less than the minimal fatal dose, so that the limits within which the diphtheria toxine can produce paralysis are distinctly wide. If the paralytic "latitude" as given in Table XV. be compared with that of toxine-antitoxine mixtures in Table XII., it appears that in the latter the boundaries lie closer together, or, in other words, a mixture of toxine and antitoxine does not cause paralysis over so wide a range of doses as is the case with the simple toxines.

Briefly to sum up the results of the experiments, and at the same time answer the questions at the beginning of the paper, we find that as far as the toxines $79 \mathrm{~A}$ and 100 are concerned-

1. Paralysis may certainly be expected after intoxication with not less than one-fourth of the minimal fatal dose. With doses between one-fourth and one-eighth paralyses occur, but are not constant, and below one-eighth no paralysis was noticed.

2. The larger the dose of toxine the severer will be the paralysis, if the animal survives long enough.

3. Neutralised mixtures of toxine and antitoxine, containing only about one lethal dose or less, do not appear to cause paralysis.

4. Antitoxine given fifteen to twenty-two hours after intoxication, with doses of toxine not greater than the lethal dose, exercises in large doses a mollifying influence on the subsequent paralysis. This influence is more evident on smaller doses of toxine than on such as are but little less than the minimal fatal dose. Small doses of antitoxine have no evident effect in diminishing the paralysis.

5. Transferring these results to practice amongst human beings, we may expect liberal doses of antitoxine, given early in the illness, to influence favourably the subsequent paralysis, and this beneficial influence is likely to manifest itself not so much on the local paralyses (soft palate, etc.) as on such symptoms as failure of the heart. Severe cases are, however, likely to be followed by some paralysis in spite of even large doses of antitoxine. 